\title{
Long-term changes in phytoplankton in a humic lake in response to the water level rising: the effects of beaver engineering on a freshwater ecosystem
}

\author{
W. Pęczuła ${ }^{(1), \star}$, A. Szczurowska ${ }^{(2)}$
}

Received April 15, 2013

Revised June 10, 2013

Accepted June 13, 2013

Key-words: water level change, humic lake, phytoplankton, beaver, Gonyostomum semen

\section{ABSTRACT}

Although water level changes are supposed to be a key factor affecting the functioning of lake ecosystems, knowledge on this topic is scarce, particularly for humic lakes. This paper presents the results of 18 years' research on a small humic lake exposed to hydrological change (rising of the water level), which was induced by spontaneous colonization of the lake by the European beaver (Castor fiber L.). We put forward a hypothesis that this change will be reflected in the quantity and structure of summer phytoplankton due to expected changes in the water chemistry. We noted a statistically significant decrease in total phosphorus and calcium concentrations, electrolytic conductivity, and Secchi disc transparency, and an increase in water color. The phytoplankton structure changed, with cyanoprocaryota and greens decreasing and flagellates increasing. The alteration was observed in a lake which had previously been drained by ditches, so beaver damming appeared to cause the return of the lake to its original endorheic conditions as well as to a water chemistry and phytoplankton structure more typical of undisturbed humic lakes.

\section{RÉSUMÉ}

Les changements à long terme dans le phytoplancton d'un lac humique en réponse à la montée des eaux : les effets de l'ingénierie des castors sur l'écosystème d'eau douce

Mots-clés : changement de niveau d'eau, lac humique, phytoplancton, castor, Gonyostomum semen
Bien que les changements de niveau d'eau soient censés être un facteur clé qui influe sur le fonctionnement des écosystèmes lacustres, les connaissances sur ce sujet sont rares, en particulier pour les lacs humiques. L'article présente les résultats d'une recherche de 18 ans sur un petit lac humique exposé au changement hydrologique (montée du niveau de l'eau), qui a été induit par la colonisation spontanée du lac par le castor d'Europe (Castor fiber L.). Nous avons proposé comme hypothèse que ce changement serait reflété dans la quantité et la structure du phytoplancton d'été en raison des changements attendus dans la chimie de l'eau. Nous avons noté une diminution statistiquement significative dans les concentrations en phosphore total et en calcium, la conductivité électrolytique, la transparence mesurée au disque de Secchi et l'augmentation de la couleur de l'eau. La structure du phytoplancton a changé avec une diminution des cyanobactéries et

(1) Department of Hydrobiology, University of Life Sciences, ul. Dobrzańskiego 37, 20-262 Lublin, Poland

(2) Department of General Ecology, University of Life Sciences, Lublin, Poland

* Corresponding author: wojciech.peczula@up.lublin.pl 
des algues vertes et une augmentation des flagellés. La modification a été observée dans un lac qui avait été préalablement drainé par des fossés, ainsi les barrages de castors semblent provoquer le retour du lac aux conditions endoréiques originales de même que pour la chimie de l'eau et la structure du phytoplancton plus typiques des lacs humiques non perturbés.

\section{INTRODUCTION}

Variability in the water recharge resulting in fluctuations in the water level, besides changes in the nutrient load, seems to be a key factor affecting the functioning of lake ecosystems, even though knowledge on this subject is still scarce (Coops et al., 2003). This particularly applies to shallow lakes where changes in the water level affect i.a. the quantity and quality of submerged macrophytes through improvement or deterioration of the light climate (Blindow, 2002; Havens et al., 2004). Rising of the water level in shallow lakes may result in transition from the macrophyte-dominated state to the cyanobacteria-dominated state, which is a consequence of changes in the relations between the mixing zone and the euphotic zone (Dokulil and Mayer, 1996). Knowledge about this type of relationship is applied in lake restoration: the monitored lowering of the water level is one of the tools used to improve the water quality in degraded lakes (Coops and Hosper, 2002). Lowering of the water level and improvement of the light climate is not always a sufficient measure to restore macrophytes, but it may induce a change in the species structure of cyanobacteria (Nõges and Nõges, 1999).

Lakes connected with peatlands, e.g. humic lakes, also seem to be a type of aquatic ecosystem that may be particularly sensitive to hydrological changes, especially when the water level changes affect both a reservoir and an adjacent wetland. This is because the physical and chemical properties of water in such lakes are strongly associated with the amount and quality of dissolved organic carbon (DOC) derived from their peatland and forest catchments (Wiliamson et al., 1999). Knowledge on water level changes in humic lakes and the impact of this phenomenon on an ecosystem is, however, extremely scanty. The final stage of the water level lowering (as a result of drying up) may effect an increase in conductivity, water color and concentrations of calcium, total phosphorus and DOC (Zieliński et al., 2011). Evidence from paleolimnological research showed that lowering of the water level (as a result of watermill demolition) induced transformation of a humic, acid lake into a clear-water and calcium-rich reservoir (Klein, 1993). On the other hand, the rising of the water level in a humic lake on a short-term scale may result in an increase in total phosphorus and DOC concentrations, as well as in changes in plankton productivity and community structure (Paterson et al., 1997; Findlay et al., 2005). Water level changes in freshwaters and consequently, changes in the biocoenosis structure can also be induced by beaver engineering, which consists mainly of water damming. The influence exerted by beaver activity on the landscape or ecosystems has often been researched, although in relation to such habitats as forests, wetlands and rivers (the review in: Rosel et al., 2005). The effects of beaver activity on lakes are hardly identified. There is one study on the impact of beavers on aquatic animals in the littoral zone of some lakes which stated that the number of species and the abundance of benthic macroinvertebrates, fish and amphibians increased in the vicinity of beaver lodges (France, 1997). There are no studies, however, on the effect of beaver-induced water damming on a lake on a broader scale, i.e. on phytoplankton, which responds relatively quickly to hydrological or chemical disturbances and is known to be a good indicator of a lake ecosystem's state. Both North American and Eurasian beavers (Castor canadensis Kuhl and C. fiber L.) are the species which spread worldwide (Rosell et al., 2005), so knowledge of their impact on freshwater ecosystems would seem to be important.

This paper presents the results of 18 years' research on a humic lake surrounded by peatlands exposed to a period of hydrological change (rising of the water level), which was induced by natural, spontaneous colonization of the lake by the Eurasian beaver (Castor fiber). We put forward a hypothesis that this change will be reflected in the quantity and the structure of summer phytoplankton due to expected changes in the composition of chemical parameters of the water in the studied lake. 

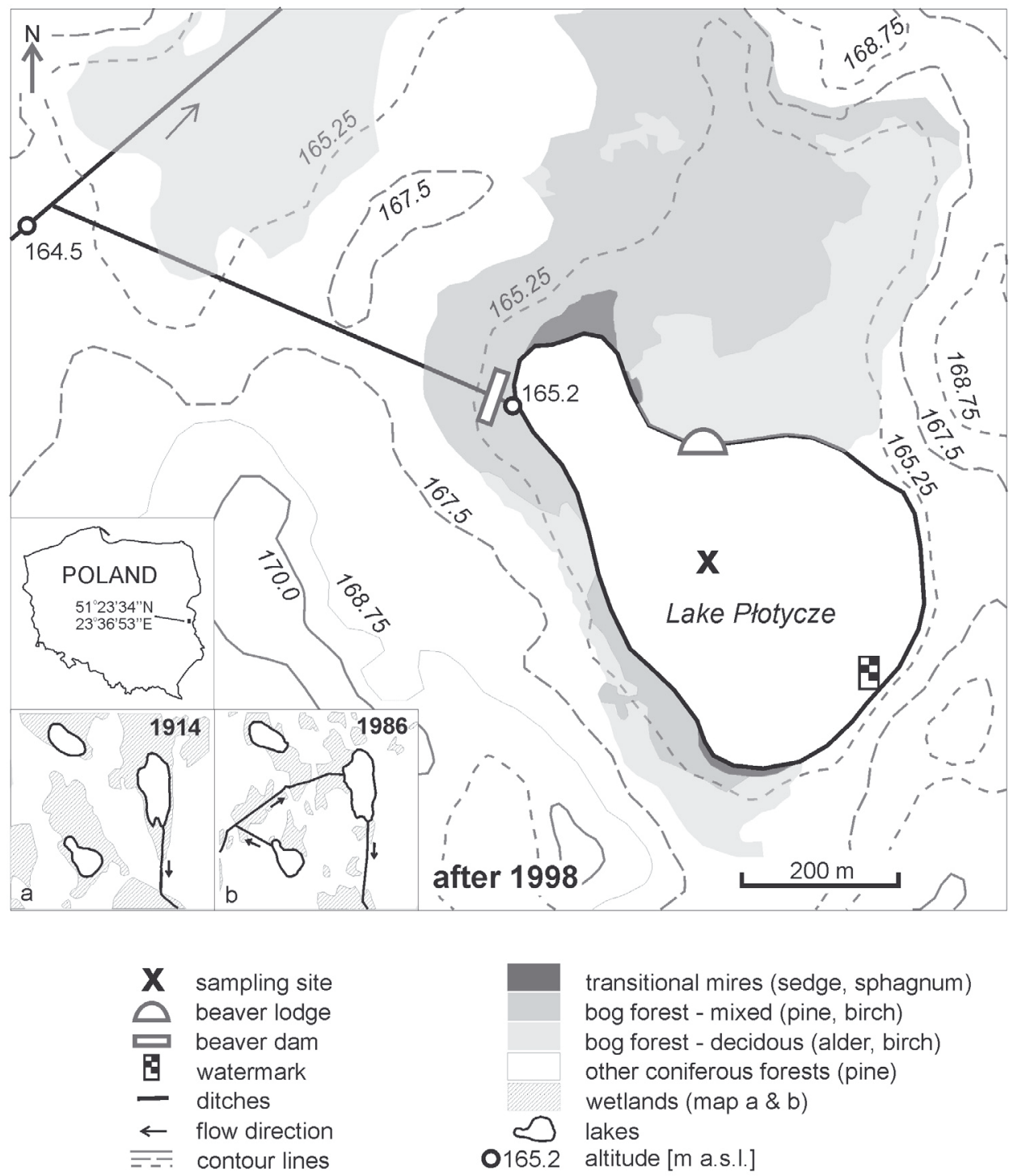

transitional mires (sedge, sphagnum) bog forest - mixed (pine, birch) bog forest - decidous (alder, birch) other coniferous forests (pine) wetlands (map a \& b)

lakes

altitude [m a.s.I.]

\section{Figure 1}

Situation map of Lake Płotycze (a, b - hydrographical changes in the area between 1914 and 1986, acc. to topographical maps: Karte de westlichen Russlands 1915. N-36. Opalin. 1: 100000; Military Topographic Map 1987. M-34-24-C. Zabużje. 1: 50000 , General Headquarters of Polish Army).

\section{MATERIAL AND METHODS}

Lake Płotycze $\left(51^{\circ} 23^{\prime} 39^{\prime \prime} \mathrm{N}, 23^{\circ} 36^{\prime} 58^{\prime \prime} \mathrm{E}\right)$ is a small $\left(160000 \mathrm{~m}^{2}\right)$, shallow (mean depth of $2.2 \mathrm{~m}$ ) water body located in eastern Poland in the region of Western Polesie (the East European Plain). The basic limnological parameters of the studied lake are presented in Table I. The lake is formed in the southern part of a topographic depression (165.25 m a.m.s.l.), which in the northern part is covered with peat deposits overgrown with bog, mostly deciduous forests, dominated by birch and alder, and peat moss in the herb layer. The depression is partly covered with mixed bog forests with a significant contribution of pine. Small fragments of open transition mire with sedge and peat moss are also found near the lake shore (Figure 1). Until the early 20th century, Lake Płotycze was probably an endorheic lake (Figure 1a). In the 1950s-1970s, forest land reclamation was carried out in the vicinity of the lake, and consequently Lake Płotycze was connected by a channel with the land reclamation system, draining 
Table I

Basic limnological data of Lake Płotycze (after Pęczuła 2007, changed).

\begin{tabular}{|l|c|}
\hline Area & $0.16 \mathrm{~km}^{2}$ \\
\hline Max depth & $6.0 \mathrm{~m}$ \\
\hline Mean depth & $2.2 \mathrm{~m}$ \\
\hline Volume & $374000 \mathrm{~m}^{3}$ \\
\hline Catchment area & $1.51 \mathrm{~km}^{2}$ \\
\hline Forests in the catchment & $70 \%$ \\
\hline Wetlands in the catchment & $23 \%$ \\
\hline Schindler's index & 4.0 \\
\hline
\end{tabular}

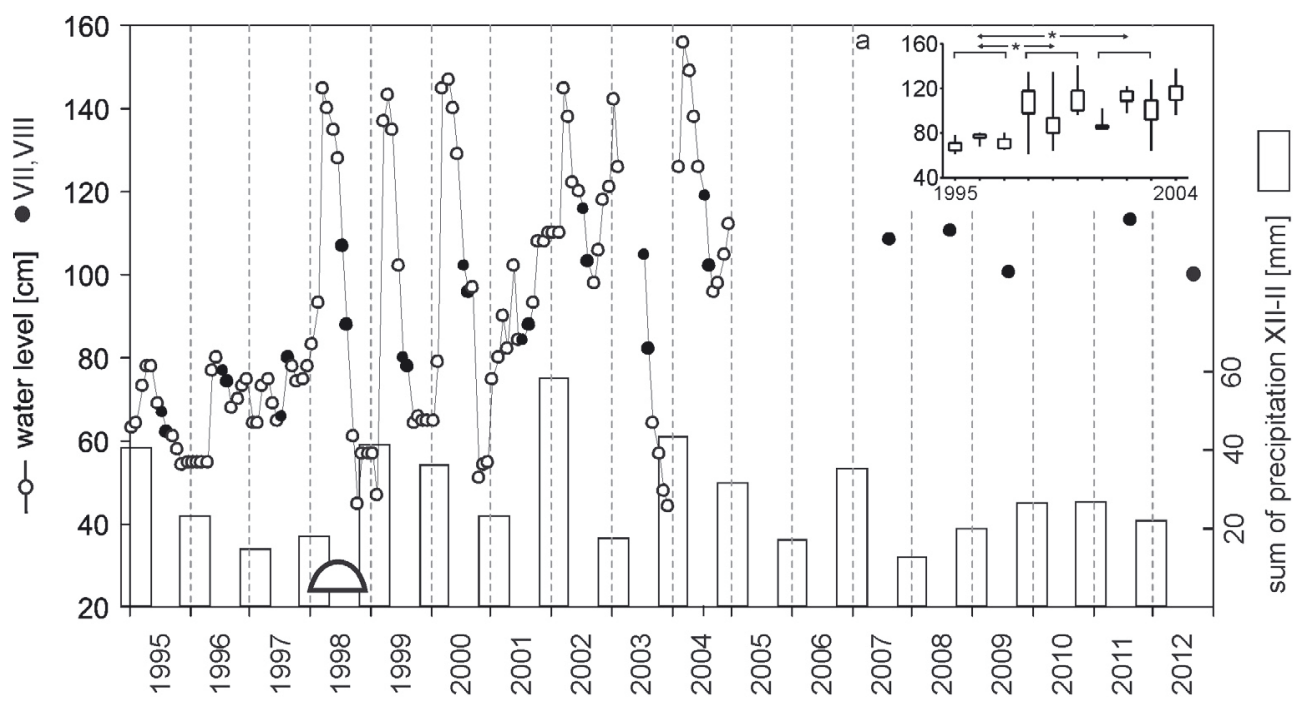

Figure 2

Changes in Lake Płotycze water level and sum of precipitation from December to February in Włodawa meteorological station between 1995 and 2012 (a: minimal-maximal values and standard deviation of water levels [cm] in the studied lake between May and October in the period of 1995-2004; asterix $P<0.001$, ANOVA). The symbol of the lodge represents the beginning of beaver activity in the lake.

the water into another nearby lake (Figure 1b). The altitude difference between the shore of Lake Płotycze (165.2 $\mathrm{m}$ a.m.s.I.) and the system of channels (164.5 m a.m.s.l.) was $0.7 \mathrm{~m}$ (Figure 1). Not only was the direction of the water cycle changed due to the forest drainage, but also the area of wetlands was reduced in this region (Figures 1a and 1b).

In 1979-1981, the Eurasian beaver (Castor fiber) was reintroduced into the region, and one of the beaver families was brought into Lake Brudzieniec, located within a distance of ca. $2 \mathrm{~km}$ north of Lake Płotycze (Kasperczyk, 1987). Since 1998-1999, the presence of beavers has been observed at Lake Płotycze in the form of feeding traces, a lodge built on the north shore of the lake and dams on a channel previously draining the water from the lake (Figure 1).

Our research on Lake Płotycze was carried out every year from 1995 to 2012 (except for 2005, 2006 and 2010). The data presented in this paper come mostly from the authors' own research but some chemical data were collected by other authors (unpublished or published data) and this is specified in the captions for Figures 3 and 4.

$2 \mathrm{~L}$ water samples for biological and chemical analysis were collected with a Ruttner sampler in July or August in the central part of the lake from the surface water layer (0.5-2 m, an integrated sample). At the same time, water transparency was measured in the lake (with a Secchi disc), as well as electrolytic conductivity and pH (YSI 556 Multi-Probe). Other parameters were determined in the laboratory: the concentration of chlorophyll-a (the ethanol method, ISO 1992), the concentration of total phosphorus (TP, the molybdate method, Hermanowicz et al., 1999) and calcium (as alkalinity by the titrimetric method with disodium EDTA in mval. $\mathrm{L}^{-1}$, later converted to $\mathrm{mg} \cdot \mathrm{Ca} \cdot \mathrm{L}^{-1}$, Hermanowicz et al., 1999), and water color (with the 


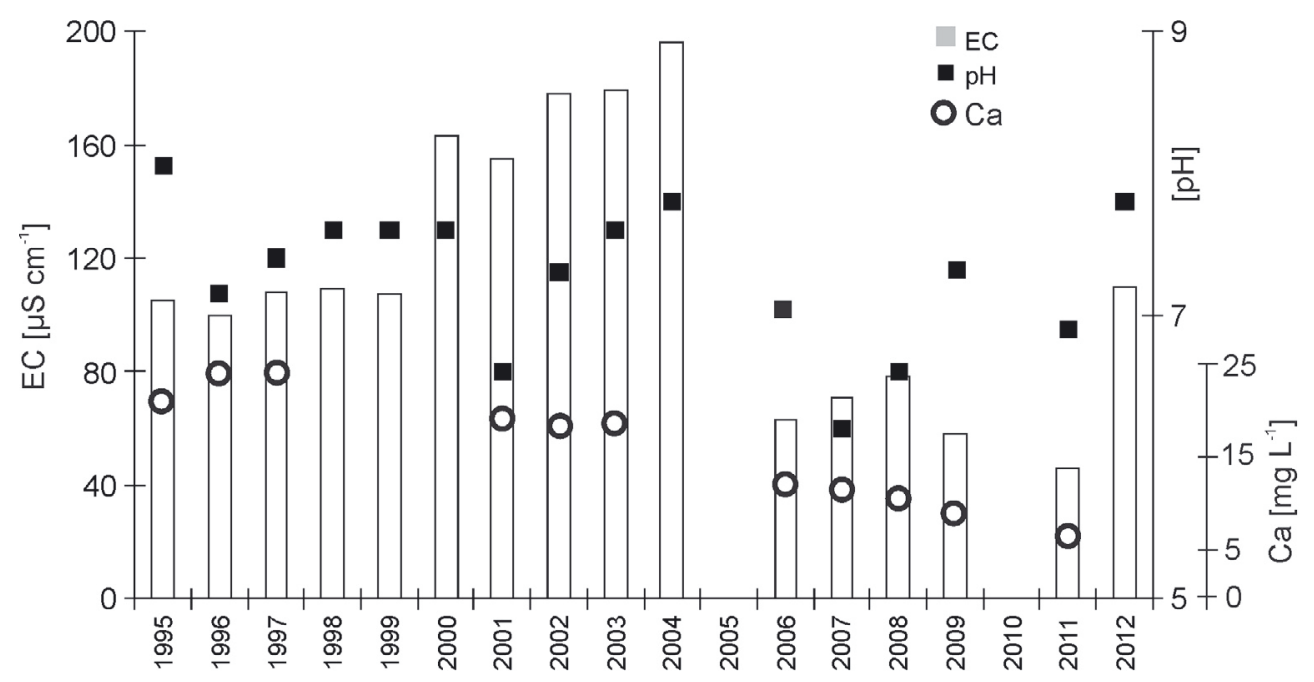

Figure 3

Electrolytic conductivity (EC), pH and calcium (Ca) concentrations in Lake Płotycze in summer between 1995 and 2012 (all values in 2006 acc. to Chmiel, unpublished; EC and pH in 2007-2008 acc. to Kolejko, unpublished; Ca in 2007, 2008 and 2009 acc. to: Voivodship Inspectorate of Environmental Protection in Lublin, unpublished, Poniewozik et al. (2011), Sender (2011), respectively).
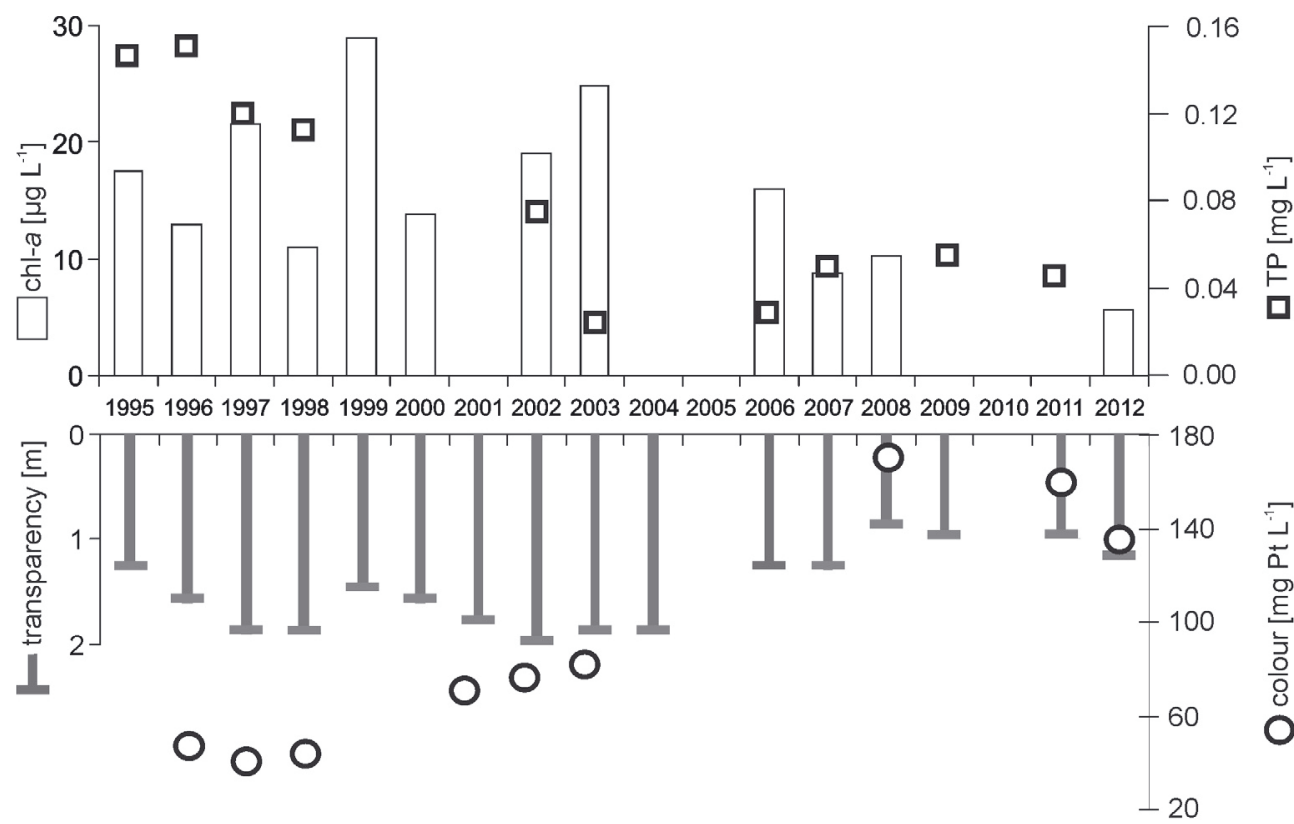

\section{Figure 4}

Chlorophyll-a and TP concentrations, water transparency and color in Lake Płotycze in summer between 1995 and 2012 (all values in 2006 acc. to Chmiel, unpublished; TP in 2006-2007 acc. to Kolejko, unpublished; water color in 2008 acc. to Poniewozik et al., 2011; TP in 2009 acc. to Sender 2011, TP and color in 2011 acc. to Wojciechowska et al., 2012).

spectrophotometric method at $440 \mathrm{~nm}$, converted to $\mathrm{mg} \mathrm{Pt} \cdot \mathrm{L}^{-1}$, Lean, 1998). Phytoplankton samples were determined using an inverted microscope and the Utermöhl method (Vollenweider, 1969) - the abundance (cells or colonies per $1 \mathrm{~L}$ ) and the biovolume $\left(\mu \mathrm{m}^{3} \cdot \mathrm{L}^{-1}\right)$ were calculated by comparing the algae cells with relevant geometric shapes (Hillebrand et al., 1999). The fresh biomass of algae was then calculated per $\mathrm{mg} \cdot \mathrm{L}^{-1}$ assuming that the density of algae cells was $1 \mathrm{~g} \cdot \mathrm{cm}^{-3}$. In 1995-2004, regular monthly measurements of the water level (expressed in $\mathrm{cm}$ ) were conducted in the lake (Polesie Landscape Parks, unpublished data). Further data on the water (2005-2012) come from the readings taken by the authors during 
Table II

$F$ values and statistical significance $\left.{ }^{* * *} P<0.001,{ }^{* *} P<0.01,{ }^{*} P<0.05\right)$ of one-way ANOVA results for analyzed hydrochemical parameters in Lake Płotycze (A - 1995-1999, B - 2000-2004, C - 2006-2011).

\begin{tabular}{|l|c|c|c|}
\cline { 2 - 4 } \multicolumn{1}{c|}{} & $\mathrm{A}-\mathrm{B}$ & $\mathrm{B}-\mathrm{C}$ & $\mathrm{A}-\mathrm{C}$ \\
\hline Conductivity & $88.4^{* * *}$ & $153.1^{* * *}$ & $55.5^{* * *}$ \\
\hline pH & 0.4 & 3.4 & $8.1^{*}$ \\
\hline Ca & $17.2^{*}$ & $237.4^{* * *}$ & $137.7^{* * *}$ \\
\hline Transparency & 2.2 & $47.2^{* * *}$ & $14.1^{* *}$ \\
\hline TP & - & - & $33.6^{* *}$ \\
\hline Color & $97.8^{* * *}$ & $57.1^{* *}$ & $118.7^{* * *}$ \\
\hline
\end{tabular}

sampling (July or August). Total precipitation for the meteorological station in the town of Włodawa, located $20 \mathrm{~km}$ from the lake, come from the climatological service www.tutiempo. net. Since the summer water levels in the lakes of the studied area are mostly related to the amount of snowfall in December-February of the previous winter, the total precipitation for this period was included in the analysis (Michalczyk et al., 2011).

The significance of changes in the hydrological and chemical parameters was analyzed with one-way ANOVA (using Gnumeric v. 1.10 .16 software) by comparing different time intervals with the same number of data. In the case of water levels, data from monthly measurements taken in the growing season (May-October) of 1995-1997, 1998-2000 and 2001-2003 were compared. After the initial data analysis and assuming a delayed response of the ecosystem to a hydrological change, the following periods were accepted for chemical parameters: 1995-1999, 2000-2004 and 2006-2011. The variability of phytoplankton in relation to changes in the water hydrochemistry was analyzed with Canonical Correspondence Analysis (CCA) using MVSP v. 3.11 software. The biomass of the 10 most common species (i.e. those that occurred in more than $50 \%$ of samples) was included in the analysis together with 4 chemical parameters of the water: $\mathrm{pH}$, electrolytic conductivity, total phosphorus concentration and water color. The autocorrelation for none of the factors used was higher than $r=0.55$.

\section{RESULTS}

\section{> HYDROLOGICAL AND HYDROCHEMICAL CHANGES}

Water levels in the lake in 1995-1997 were characterized by small fluctuations between May and October (mean: 67.4-75.2 cm, SD: 4.5-6.9 cm). The annual maximum water levels were similar and did not exceed $78-80 \mathrm{~cm}$, and occurred in various months: May, June or August. Water levels in the summer months (July/August) were within the range of $62-80 \mathrm{~cm}$. The dynamics of water level changes was different from 1998 - mean values between May and October ranged from 90.2 to $116.2 \mathrm{~cm}$ (SD 7.6-30.2 cm). Also, the maximum levels (recorded every year in May) were higher compared with the previous period and ranged from 122 to $140 \mathrm{~cm}$ (except for 2001-102 cm). In the summer, water levels in the lake ranged from 78 to $119 \mathrm{~cm}$ (Figure 2). The difference between the first three years (1995-1997) and the following years $(1998-2000 ; 2001-2003)$ was statistically significant $(F=20.5, P<0.001$ and $F=34.1$, $P<0.001$, respectively; ANOVA); whereas there was no such difference between 1998-2000 and 2001-2003 ( $F=0.09, P=0.7$, ANOVA; Figure 2a). In the last period (2007-2012) the water levels in summer ranged from 100 to $117 \mathrm{~cm}$.

Total precipitation in the winter half-year preceding a given growing season was on average $28.1 \pm 12.2 \mathrm{~mm}$ (ranging from 12.7-58.4 mm). Both in the period of low water levels in the lake (before 1998) and in the later period, there were years with low precipitation - ranging from 12 to $17 \mathrm{~mm}(1997,1998,2003,2006,2008)$, and years with precipitation above $40 \mathrm{~mm}$ (1995, 2002, 2004: Figure 2).

The chemical parameters of the water changed during the study period. In 1995-1999, electrolytic conductivity (EC) was 100-109 $\mu \mathrm{S} \cdot \mathrm{cm}^{-1}$; in the following period (2000-2004) the values 


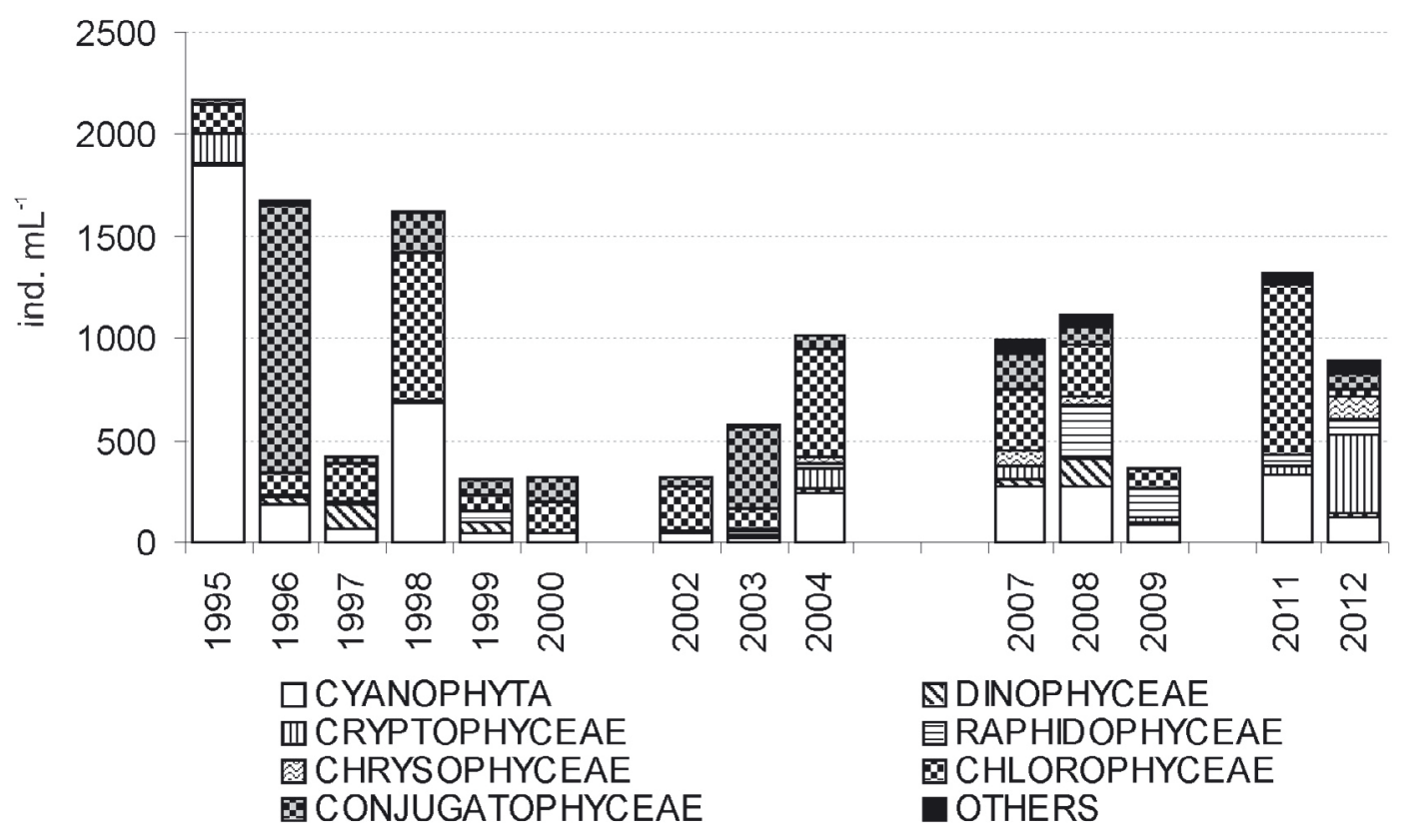

\section{Figure 5}

The abundance of phytoplankton taxonomic groups in Lake Płotycze in summer between 1995 and 2012.

were significantly higher $(F=88.4, P<0.001$, ANOVA $)$ and ranged from $155-196 \mu \mathrm{S} \cdot \mathrm{cm}^{-1}$. In the last years (2006-2012), these values were much lower, did not exceed $78 \mu \mathrm{S} \cdot \mathrm{cm}^{-1}$ (except for the last year: $110 \mu \mathrm{S} \cdot \mathrm{cm}^{-1}$ ) and differed statistically from the previous periods (Table II). Nevertheless, changes in the calcium concentration did not exactly correspond to changes in the conductivity (increase-decrease); the values gradually decreased during the study period (from 21.0-24.0 mg. $\mathrm{L}^{-1}$ to $6.4-10.7 \mathrm{mg} \cdot \mathrm{L}^{-1}$ ) and the difference between the first and last periods was statistically significant (Table II). Water $\mathrm{pH}$ was not constant; at first, values fluctuated within the range of 7.2-7.8, and after 2006 within a broader range of 6.2-7.8 (Figure 3). Total phosphorus concentrations were relatively high in the beginning $\left(0.112-0.051 \mathrm{mg} \cdot \mathrm{L}^{-1}\right)$ and then twice as low after 2006 (0.029-0.055 mg. $\mathrm{L}^{-1}$, Figure 4; $F=33.6, P<0.01$, ANOVA). The values of Secchi disc visibility in the first ten years of the study fluctuated within the range of 1.3-1.9 $\mathrm{m}$ and after 2006 they decreased to $0.9-1.3$, which was accompanied by a gradual increase in the water color (Figure 4). Changes in both parameters during the study were statistically significant (Table II).

\section{> PHYTOPLANKTON}

Chlorophyll-a concentrations in the study period were characterized by large fluctuations and their average value was $19.1 \pm 16.7 \mu \mathrm{g} \cdot \mathrm{L}^{-1}$ (ranging from 4.3-59.1 $\mu \mathrm{g} \cdot \mathrm{L}^{-1}$ ). In 1995-1997 when the water levels were low, the values of this parameter were relatively low $\left(7.6-12.9 \mu \mathrm{g} \cdot \mathrm{L}^{-1}\right)$. The highest values of chlorophyll-a were recorded in 2001-2003 when they were two or three times higher compared with the initial period of the study $\left(24.8-59.1 \mu \mathrm{g} \cdot \mathrm{L}^{-1}\right)$. After 2006 the chlorophyll-a concentrations did not exceed the value of $16.3 \mu \mathrm{g} \cdot \mathrm{L}^{-1}$ (Figure 4). We compared the differences in the values of this parameter for the same three periods, as in the case of the chemical data. The difference between the initial $(A)$ and the last $(C)$ period was not significant $(F=0.1, P=0.76$, ANOVA), while the differences in the chlorophyll-a concentration between $A$ and $B$, and between $B$ and $C$ were statistically significant $(F=6.1, P<0.05 ; F=6.2$, $P<0.05$, ANOVA, respectively).

Eighty-seven taxa of algae were identified during the study period, of which the most frequently represented were chlorophytes and cyanophytes. The floristic structure of phytoplankton in subsequent years was similar, with the most frequent (occurring in $>50 \%$ of 


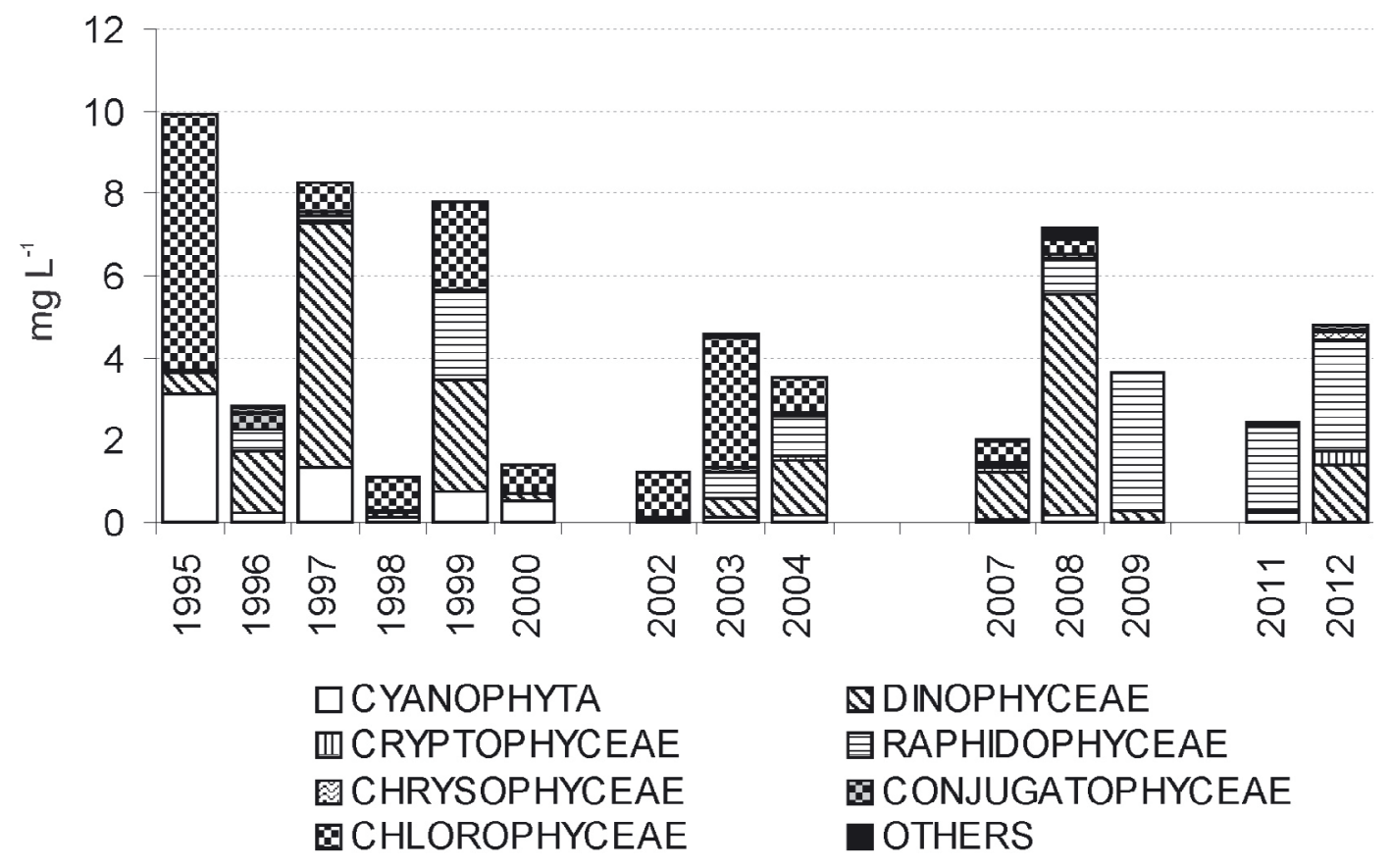

Figure 6

The biomass of phytoplankton taxonomic groups in Lake Płotycze in summer between 1995 and 2012.

samples) species being: Chroococcus limneticus Lemmerm. and Woronichinia naegeliana (Unger) Elenkin (Cyanoprokaryota), Peridinium bipes F. Stein and Ceratium hirundinella (O. F. Müll.) Bergh (Dinophyta), Cryptomonas sp. (Cryptophyceae), Gonyostomum semen (Ehrenb.) Diesing (Raphidophyceae), Dinobryon divergens O. E. Imhof (Chrysophyceae), Botryococcus braunii Kütz. and Quadrigula closterioides (Bohlin) Printz (Chlorophyceae), as well as Closterium acutum var. variabile (Lemm.) Willi Krieg. (Conjugatophyceae).

The total abundance of phytoplankton ranged from 306.2 to $2169.9 \mathrm{ind} \cdot \mathrm{mL}^{-1}$. The highest abundance of phytoplankton was observed before beaver damming, i.e. in 1995, 1996 and 1998 (Figure 5), with some coccal cyanobacteria, Dactylococcopsis sp. Aphanothece clathrata, Chroococcus limneticus and Woronichinia naegeliana, and small green algae, Quadrigula closterioides and Closterium acutum var. variabile, as the main constituents. In the subsequent years (after damming), the abundance of phytoplankton remained at a low level, and coccal green algae (including Closterium acutum) dominated. In the last period (after 2006), the abundance of phytoplankton fluctuated, but remained at a relatively constant level. At that time, in addition to Cyanoprokaryota and Chlorophyta, the following species contributed to the phytoplankton abundance: Gonyostomum semen (Raphidophyceae), Peridinium bipes (Dinophyceae), Cryptomonas sp. (Cryptophyceae) and various species from Chrysophyceae.

The highest values of the total phytoplankton biomass were recorded at the beginning of the study period, before beaver activity (mean: $5.9 \mathrm{mg} \cdot \mathrm{L}^{-1}$; range: $1.1-9.9 \mathrm{mg} \cdot \mathrm{L}^{-1}$ ). During that period, various cyanobacteria as well as the green alga Botryococcus braunii and the dinophyte Peridinium bipes made the largest contribution to the biomass. After the increase in the water level, the biomass of phytoplankton remained at a lower level (mean: $3.4 \mathrm{mg} \cdot \mathrm{L}^{-1}$; range: $1.2-7.1 \mathrm{mg} \cdot \mathrm{L}^{-1}$ ) and was also dominated by Botryococcus braunii and Peridinium bipes, but with a high contribution of Gonyostomum semen. A large increase in the biomass was observed in 2008 ( $\left.7.1 \mathrm{mg} \cdot \mathrm{L}^{-1}\right)$ when Peridinium bipes was the only one dominant. After 2008 the dominance structure of the total phytoplankton biomass changed - the contribution of flagellate forms (represented mainly by Gonyostomum semen and Cryptomonas sp.) increased, while no significant contribution of cyanobacteria or green algae was observed (Figure 6). 


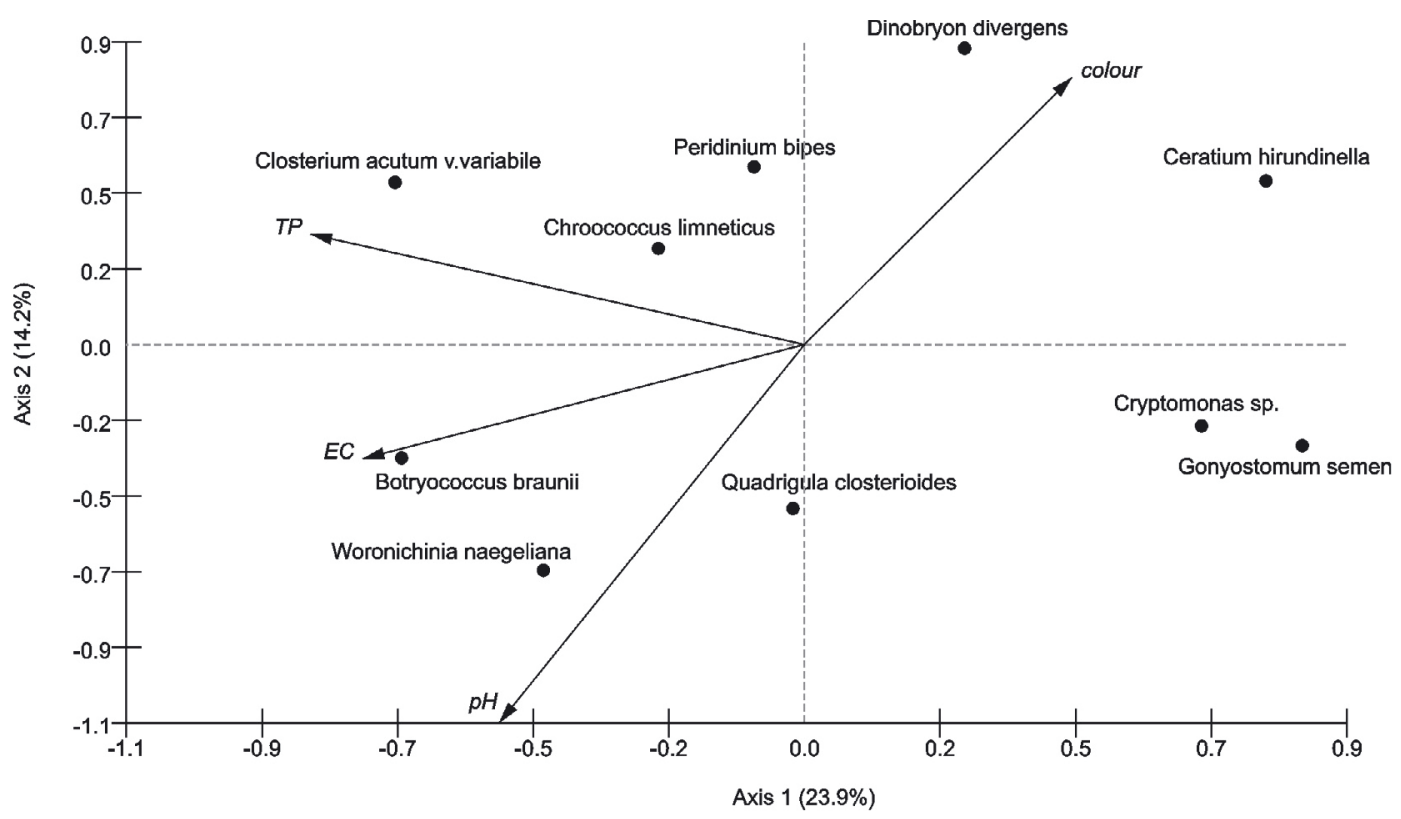

\section{Figure 7}

The ordination scatter plot of the CCA based on hydrochemical data and the biomass of the most frequent species (EC - electrolytic conductivity; TP - total phosphorus concentration).

As evidenced by Canonical Correspondence Analysis (CCA), all four parameters ( $\mathrm{pH}$, EC, TP and color) were equally correlated with the axes representing the variability in the analyzed biomass of the most frequent species (Figure 7). The first two axes (eigenvalues: 0.326 and 0.193 , respectively) accounted together for $38.1 \%$ of the data variance. TP $(-0.52)$ and EC $(-0.46)$ were most strongly correlated with the first axis, and $\mathrm{pH}(-0.62)$ and water color $(0.44)$ with the second axis. The following species positively responded to higher values of TP and EC (axis 1): Closterium acutum var. variabile, Botryococcus braunii, Woronichinia naegeliana and Chroococcus limneticus; while species of flagellates were at the other side of this axis (Gonyostomum semen, Cryptomonas sp., Dinobryon divergens, Ceratium hirundinella). According to the ordination diagram, some of the flagellates ( $D$. divergens, $C$. hirundinella) show preferences for low pH and high values of color (axis 2), while G. semen and Cryptomonas $\mathrm{sp}$. were not so strongly correlated with these parameters. Another flagellate species, the dinophyte Peridinium bipes, which often significantly contributed to the total phytoplankton biomass, appeared in the middle part of the gradient consisting of factors represented by $\mathrm{CCA}$ axis 1 . Lower $\mathrm{pH}$ and higher water color (axis 2) were yet other parameters correlated with the biomass of this species.

\section{DISCUSSION}

Our hypothesis was based on the assumption that the water level rise in the lake resulting from beaver damming should induce a change in the water chemical parameters. We also expected structural changes in the summer phytoplankton - a community that quickly responds to alterations in water chemistry. As shown by the results, both expected changes took place in a long-term perspective.

The water level change in Lake Płotycze, after the water outflow was dam-blocked by beavers, was statistically significant and multidirectional: the maximum water levels increased, their dates changed, and annual variability and summer water levels increased. The difference between the maximum water levels before and after damming was ca. $70 \mathrm{~cm}$, which corresponds to the difference in the altitude between the lake shore (165.2 m a.m.s.l.) and the system of draining channels ( $164.5 \mathrm{~m}$ a.m.s.l.). This may prove that beaver activity led 
to the restoration of the primary hydrology in the lake - a hundred years ago, a water body without drainage. It appears that the increase in the maximum water levels by $70 \mathrm{~cm}$ also affected the hydration of wetlands adjacent to the lake. The former are located in an area with an altitude of only a few centimeters higher in relation to the altitude of the lake. Unfortunately, we are not able to support this hypothesis with measurements of the groundwater level or the soil moisture in the wetlands; instead, we can only rely on our field observations that confirm this trend.

The hydrochemical changes observed in the lake were related to a few parameters: an increase in the water color (and reduced transparency) and a decrease in total phosphorus and calcium concentrations, and a decrease in electrolytic conductivity, which followed after the initial increase. It is difficult to explain the observed changes only by the variability in precipitation recharge: the total precipitation changed every year, but no clear trend was observed in the area where the analyzed lake is located (Michalczyk et al., 2011). Due to the very small number of long-term studies on this type of ecosystem, it is also difficult to determine whether this type of change in the hydrochemistry of a humic lake reflects natural fluctuations. Keskitalo et al. (1998), who studied a small and shallow humic lake for seven years, reported relatively high fluctuations in the water color, ranging from 103 to $178 \mathrm{mg} \cdot \mathrm{Pt} \cdot \mathrm{L}^{-1}$, while changes in the values of conductivity and total phosphorus concentration were very small. Thus, the changes described in Lake Płotycze could be related mainly to changes in the amount and quality of the matter imported from the peat-bog catchment. A hypothetical return of peat bogs surrounding a lake to normal hydration could bring about a return of wetlands to their regular state of phosphorus retention (Reddy et al., 1999; Kieckbusch and Schrautzer, 2007). In the case of wetlands with Sphagnum, intensive retention of calcium also occurs (Hillbricht-llkowska et al., 1998; Hehmann et al., 2001). One should remember, however, that re-flooding of the previously dried peat bogs may at first initiate the increased export of chemical elements into waters (Tiemeyer et al., 2005; Zak and Gelbrecht, 2007), although this process is determined by several chemical and hydrological factors (Urbanová et al., 2011). An increase in phosphorus and nitrogen contents was also observed in the first three years after lake impoundment and flooding of surrounding peatlands in one experimental lake in Canada (Paterson et al., 1997; Findlay et al., 2005). The increased values of conductivity in Lake Płotycze, after the rise in the water level, may result from this particular phenomenon. On the other hand, the decreasing concentration of phosphorus and calcium in Lake Płotycze may result from the complexation of chemical elements with humic compounds (Jones, 1998; Wetzel, 1992), assuming that the higher values of water color observed in the lake reflected the increased amount of humic compounds. The observed increase in the water color in Lake Płotycze results either from the increased export from peat bogs after their rewetting (Zak and Gelbert, 2007) or from the general trend consisting of the increasing amount of DOC (and color), which has been observed for several years in European freshwaters (Evans et al., 2005; Vuorenmaa et al., 2006). Unfortunately, we do not have long-term data for other lakes in this area, thus it is difficult to determine whether this trend is significant in the case of the studied lake.

The response of summer phytoplankton to changes in the water level in Lake Płotycze consisted mainly of the reduced contribution of cyanobacteria and green algae, and the increased contribution of flagellate species. CCA analysis proved that higher values of conductivity, $\mathrm{pH}$ and total phosphorus concentration (which corresponded to conditions before the water damming) were favorable to species such as Closterium acutum var. variabile, Woronichinia naegeliana, Chroococcus limneticus and Botryococcus braunii. The first two species are recognized as species of slightly alkaline lakes with moderate and high nutrient content (Rosen, 1981; Coesel, 1993; Reynolds and Petersen, 2000; Wilk-Woźniak and Mazurkiewicz-Boroń, 2003), whereas Chroococcus limneticus and Botryococcus braunii are usually found in mesotrophic water bodies, including humic ones (Naselli-Flores and Barone, 2000; Holopainen et al., 2003). Lower values of $\mathrm{pH}$, TP and EC, and the increased water color (after damming) were correlated with the increased biomass of some flagellates, including Dinobryon divergens, Ceratium hirundinella and, to a lesser extent, Cryptomonas sp. and 
Gonyostomum semen. High contribution of flagellates, including mixotrophic species, is often recognized as a characteristic feature of low-productive humic lakes (Jones, 1998; Nürnberg and Shaw, 1998). Increase in Gonyostomum semen biomass was also reported by Findlay et al. (2005) after experimental water level raising which was associated with total phosphorus and DOC increase. The species is recognized as an indicator of various changes in humic lakes and its expansion has also been observed in European lakes since the 1980s (including lakes in eastern Poland; Lepistö et al., 1994; Hutorowicz et al., 2006; Rengefors et al., 2012). Thus, the increased contribution of the species in Lake Płotycze may also be related to factors other than the water level change: according to one of the most recent hypotheses, climatic changes account for the increased contribution of this species observed in most lakes of northern Europe (Rengefors et al., 2012).

The results of our research indicate that spontaneous colonization of the ecosystem by beavers, followed by their engineering activity consisting of the water level rising, may contribute to a positive change in a humic lake. We put forward a hypothesis that the change consisted of a return of the lake previously affected by drainage to characteristics typical of humic lakes (lower conductivity, lower concentrations of calcium and phosphorus, stronger color, lower contribution of cyanobacteria and higher contribution of flagellates). Paleolimnological research could provide some evidence to support this hypothesis by revealing the earlier structure of phytoplankton in relation to hydrological changes occurring in the lake over the last hundred years. Research on the impact of beaver engineering activity on lake ecosystems is worth continuing because of the worldwide spread of the species (Rosell et al., 2005) and the potential possibility of using the colonization of beavers as one of the tools in restoration of previously drained humic lakes.

\section{ACKNOWLEDGEMENTS}

We are grateful to the following people and institutions for different forms of help: Władysława Wojciechowska - microscopic and field work, Radosław Mencfel - field sampling and chemical analyses, Stanisław Chmiel and Marcin Kolejko - providing some chemical data, and Polesie Landscape Parks - providing water level data.

\section{REFERENCES}

Blindow I., 1992. Long- and short-term dynamics of submerged macrophytes in two shallow eutrophic lakes. Freshwat. Biol., 28, 15-27.

Coesel P.F.M., 1993. Poor physiological adaptation to alkaline culture conditions in Closterium acutum var. variabile, a planktonic desmid from eutrophic waters. Eur. J. Phycol., 28, 53-57.

Coops H. and Hosper H., 2002. Water-level management as a tool for the restoration of shallow lakes in the Netherlands. Lake Reserv. Manage., 18, 293-298.

Coops H., Beklioglu M. and Crisman T.L., 2003. The role of water-level fluctuations in shallow lake ecosystems - workshop conclusions. Hydrobiologia, 506-509, 23-27.

Dokulil M.T. and Mayer J., 1996. Population dynamics and photosynthetic rates of a Cylindrospermopsis - Limnothrix association in a highly eutrophic urban lake, Alte Donau, Vienna, Austria. Arch. Hydrobiol. (Suppl.) (Algol. Stud.), 117, 179-195.

Evans C.D., Monteith D.T. and Cooper D.M., 2005. Long-term increases in surface water dissolved organic carbon: Observations, possible causes and environmental impacts. Environ. Pollut., 137, 55-71.

Findlay D.L., Paterson M.J., Hendzel L.L. and Kling H.J., 2005. Factors influencing Gonyostomum semen blooms in a small boreal reservoir lake. Hydrobiologia, 533, 243-252.

France R.L., 1997. The importance of beaver lodges in structuring littoral communities in boreal headwater lakes. Can. J. Zool., 75, 1009-1113.

Havens K.E., Sharfstein B., Brady M.A., East T.L. and Harwell M.C., 2004. Recovery of submerged plants from high water stress in a large subtropical lake in Florida, USA. Aquat. Bot., 78, 67-82. 
Hehmann A., Krienitz I., and Koschel R., 2001. Long-term phytoplankton changes in an artificially divided, top-down manipulated humic lake. Hydrobiologia, 448, 83-96.

Hermanowicz W., Dojlido J., Dożańska W., Koziorowski B. and Zerbe J. 1999. Physical-chemical investigation of water and sewage, Wydawnictwo Arkady, Warszawa, 274.

Hillbricht-Ilkowska A., Dusoge K., Ejsmont-Karabin J., Jasser I., Kufel I., Ozimek T., Rybak J.I., Rzepecki M. and Węgleńska T., 1998. Long term effects of liming in a humic lake: Ekosystem processes, biodiversity, food web functioning (Lake Flosek, Masurian Lakeland, Poland). Ekol. Pol., 46, 347-415.

Hillebrand H., Dürselen C.D., Kirschtel D., Pollingher U. and Zohary T., 1999. Biovolume calculation for pelagic and benthic microalgae. J. Phycol., 35, 403-424.

Holopainen A.-L., Niinioja R. and Rämö A., 2003. Seasonal succession, vertical distribution and long term variation of phytoplankton communities in two shallow forest lakes in eastern Finland. Hydrobiologia, 506-509, 237-245.

Hutorowicz A., Szelag-Wasielewska E., Grabowska M., Owsianny P.M., Pęczuła W. and Luścińska M., 2006. The occurence of Gonyostomum semen (Raphidophyceae) in Poland. Fragm. Flor. Geobot. Polonica, 13, 399-407.

ISO 10260, 1992. Water quality - Measurement of biochemical parameters - Spectrometric determination of the chlorophyll-a concentration, PKN, Warszawa.

Jones R.I., 1998. Phytoplankton, primary production and nutrient cycling. In: Hessen D.O. and Tranvik L. (eds.), Aquatic Humic Substances. Ecology and Biogeochemistry. Springer-Verlag, Berlin, Heidelberg, 145-175.

Kasperczyk B., 1987. Rozprzestrzenienie siê bobra (Castor fiber L.) w Europie w XX wieku. Przeg. Zool., 31, 181-193.

Keskitalo J., Salonen K. and Holopainen A.L., 1998. Long-term fluctuations in environmental conditions, plankton and macrophytes in a humic lake, Valkea-Kotinen. Boreal. Environ. Res., 3, 251-262.

Kieckbusch J.J. and Schrautzer J., 2007. Nitrogen and phosphorus dynamics of a re-wetted shallowflooded peatland. Sci. Total. Environ., 380, 3-12.

Klein T., 1993. Impact on lake development of changed agricultural watershed exploitation during the last three centuries. Hydrobiologia, 251, 297-308.

Lean D., 1998. Attenuation of solar radiation in humic waters. In: Hessen D.O. and Tranvik L.J. (eds.), Aquatic humic substances, Ecology and Biogeochemistry, Springer-Verlag, Berlin, Heidelberg, 109-124.

Lepistö L., Antikainen S. and Kivinen J., 1994. The occurrence of Gonyostomum semen (Ehr.) Diesing in Finnish lakes. Hydrobiologia, 273, 1-8.

Michalczyk Z., Chmiel S. and Turczyński M., 2011. Lake water stage dynamics in the Łêczna-Włodawa Lake District in 1991-2010. Limnol. Rev., 11, 113-122.

Naselli-Flores L. and Barone R., 2000. Phytoplankton dynamics and structure: a comparative analysis in natural and man-made water bodies of different trophic state. Hydrobiologia, 438, 65-74.

Nõges T. and Nõges P., 1999. The effect of extreme water level decrease on hydrochemistry and phytoplankton in a shallow eutrophic lake. Hydrobiologia, 408-409, 277-283.

Nürnberg G.K. and Shaw M., 1998. Productivity of clear and humic lakes: nutrients, phytoplankton, bacteria. Hydrobiologia, 382, 97-112.

Paterson M.J., Findlay D., Beaty K., Findlay W., Schindler E.U., Stainton M. and McCullough G., 1997. Changes in the planktonic food web of a new experimental reservoir. Can. J. Fish. Aquat. Sci., 54, 1088-1102.

Pęczuła W., 2007. Mass development of the algal species Gonyostomum semen (Raphidophyceae) in the mesohumic Lake Płotycze (central-eastern Poland). Ocean. Hydrobiol. Stud., 36 (Suppl. 1), 163-172.

Poniewozik M., Wojciechowska W. and Solis M., 2011. Dystrophy or eutrophy: phytoplankton and physicochemical parameters in the functioning of humic lakes. Ocean. Hydrobiol. Stud., 40, 22-29.

Reddy K.R., Kadlec R.H., Flaig E. and Gale P.M., 1999. Phosphorus retention in streams and wetlands: A review. Crit. Rev. Env. Sci. Tech., 29, 83-146.

Rengefors K., Weyhenmeyer G.A. and Bloch,I., 2012. Temperature as a driver for the expansion of the microalga Gonyostomum semen in Swedish lakes. Harmful Algae, 18, 65-73. 
Reynolds C.S. and Petersen A.C., 2000. The distribution of planktonic Cyanobacteria in Irish lakes in relation to their trophic states. Hydrobiologia, 424, 91-99.

Rosell F., Bozser O., Collen P. and Parker H., 2005. Ecological impact of beavers Castor fiber and Castor canadensis and their ability to modify ecosystems. Mammal. Rev.,35, 248-276.

Rosen G. 1981. Phytoplankton indicators and their relations to certain chemical and physical factors. Limnologica, 13, 263-290.

Salonen K. and Rosenberg M., 2000. Advantages from diel vertical migration can explain the dominance of Gonyostomum semen (Raphidophyceae) in a small, steeply-stratified humic lake. J. Plank. Res., 22, 1841-1853.

Sender J., 2011. Development of floating-leaved vegetation in three lakes of varied trophy (LecznaWlodawa Lakeland). Limnol. Rev., 11, 163-169.

Tiemeyer B., Lennartz B., Schlichting A. and Vegelin K., 2005. Risk assessment of the phosphorus export from a re-wetted peatland. Phys. Chem. Earth., 30, 550-560.

Urbanová Z., Picek T. and Bárta J., 2011. Effect of peat re-wetting on carbon and nutrient fluxes, greenhouse gas production and diversity of methanogenic archaeal community. Ecol. Eng., 37, 10171026.

Vollenweider R.A., 1969. A manual on methods for measuring primary production in aquatic environments, Blackwell, Oxford-Edinburgh, 213.

Vuorenmaa J., Forsius M. and Mannio, J., 2006. Increasing trends of total organic carbon concentrations in small forest lakes in Finland from 1987 to 2003. Sci. Total. Environ., 365, 47-65.

Wetzel R.G., 1992. Gradient-dominated ecosystems: sources and regulatory functions of dissolved organic matter in freshwater ecosystems. Hydrobiologia, 229, 181-198.

Williamson C.E., Morris D.P., Pace M.L. and Olson O.G., 1999. Dissolved organic carbon and nutrients as regulators of lake ecosystems: resurrection of a more integrated paradigm. Limnol. Oceanogr., 44, 795-203.

Wilk-Woźniak E., and Mazurkiewicz-Boroń G. 2003. The autumn dominance of cyanoprokaryotes in a deep meso-eutrophic submontane reservoir. Biologia, 58, 17-24.

Wojciechowska W., Solis M. and Mencfel R., 2012. Phytoplankton as an ecological criterion for differentation of mid-forest lakes in Sobibór Landscape Park. Teka Kom. Ochr. Kszt. Ňrod. Przyr., 9, 260-266.

Zak D. and Gelbrecht J., 2007. The mobilisation of phosphorus, organic carbon and ammonium in the initial stage of fen rewetting (a case study from NE Germany). Biogeochemistry, 85, 141-151.

Zieliński P., Ejsmont-Karabin J., Grabowska M. and Karpowicz M., 2011. Ecological status of shallow Lake Gorbacz (NE Poland) in its final stage before drying up. Ocean. Hydrobiol. Stud., 40, 1-12. 